TITLE:

\title{
ON THE SPECIES OF THE GENUS OXYNOE RAFINESQUE, 1819 FROM JAPAN, INCLUSIVE OF A NEW SPECIES (OPISTHOBRANCHIA: ASCOGLOSSA)
}

$\operatorname{AUTHOR}(S)$ :

Hamatani, Iwao

CITATION:

Hamatani, Iwao. ON THE SPECIES OF THE GENUS OXYNOE RAFINESQUE, 1819 FROM JAPAN, INCLUSIVE OF A NEW SPECIES (OPISTHOBRANCHIA : ASCOGLOSSA).

PUBLICATIONS OF THE SETO MARINE BIOLOGICAL LABORATORY 1980, 25(5-6): 349-360

\section{ISSUE DATE:}

1980-11-15

URL:

http://hdl.handle.net/2433/176004

RIGHT: 


\title{
ON THE SPECIES OF THE GENUS OXYNOE RAFINESQUE, 1819 FROM JAPAN, INGLUSIVE OF A NEW SPEGIES (OPISTHOBRANGHIA: ASCOGLOSSA)
}

\author{
IWAo HAMATANI \\ Tennoji Senior High School of Osaka Kyoiku University
}

With Text-figures $1-6$ and Plates $I-I V$

Of the genus Oxynoe Rafinesque, 1819 only a single species, O. viridis (Pease, 1861), has been recorded so far from Japan; by the shell by Habe, T. (1949) and by the soft body by Baba, K. (1952 and 1955). On the other hand, descriptions of this species had been made on foreign specimens mainly by Pease, H. (1868), Pilsbry, H. A. (1895), Eliot, C. (1906), Burn, R. (1966) and others.

Recently, a very important imformation of a questionable form belonging to this genus, collected from Kabira Bay of Ishigaki-jima Island, was brought to the present author by Mr. Koji Kitao. Then, the author collected by himself some specimens of the same form from Ishigaki-jima Island and Kuro-shima Island in April and May of 1977 respectively; both islands are situated in the southwestern part of the Ryukyu Islands. Further, one more specimen was collected by Mr. K. Kitao from Middle Japan in July of 1979 and brought to the present author in the living state.

This questionable form resembles $O$. viridis closely in main features, but in the colouration of the parapodium. Detailed and careful examinations of these specimens of the questionable form has revealed that they are not conspecific with $O$. viridis, but seemingly represent a new species separated distinctly from viridis. In the present paper, in addition to the description of this new species, the author is also going to redescribe $O$. viridis in comparison with the new species, though the anatomical features are reserved for another paper in near future.

Before closing the introductory note, the author wishes to acknowledge his thanks to Mr. Koji Kitao who kindly presented him the first information and a fresh animal of the new species for the present study, also to Mr. Masao Tamashiro, the head of the Yaéyama Branch of Okinawa Prefectural Fisheries Experimental Station, and Mr. Masayoshi Murakoshi, one of the staff of the station, whose kind appreciation enabled the author to carry out his study at that station. Lastly, the author is much obliged to Dr. Kikutaro Baba for his suggestions and to Dr. Takashi Tokioka for his kindness in reading the manuscript.

Publ. Seto Mar. Biol. Lab., XXV(5/6), 349-360, 1980.

(Article 23) 


\section{Genus Oxynoe Rafinesque, 1819 \\ =Icarus Forbes, 1844 \\ =Lophocercus Krohn, 1847}

Type species: Oxynoe olivacea (Rafinesque, 1819)

Oxynoe viridis (Pease, 1861)
=Lophocercus viridis Pease, 1861

(Japanese name: Nagisano-tsuyu)

Main synonymy: Lophocercus viridis Pease, 1861 p. 246; 1868 pp. 74-75, Pl. 8, figs. 1-2, Pl. 12, fig. 25; Eliot 1906 pp. 301-305, figs. 1-2, Pl. 5, fig. 5.

Oxynoe viridis. Pilsbry 1895 p. 165, Pl. 11, figs. 51-55; Habe 1949 pp. 79-80; Baba 1952 pp. 77-80, figs. 1-8; 1955 pp. 7-8, 40, figs. 4-5, Pl. 11, figs. 3-5; Burn 1966 pp. 55-58, figs. 20-25, 37.

Materials: The specimens examined in this study were all collected by the present author himself from the Cape Shiono-misaki at the southern-most end of Wakayama Prefecture in Middle Japan, Amami-oshima Island and Yoron-to Island of the Amami Islands, and Kabira Bay of Ishigaki-jima Island and Kuroshima Island of the Yaéyama Islands.

Description: The living animals are limaciform and up to about $30 \mathrm{~mm}$ in total length (Pl. I). The visceral mass is roundish in outline and wrapped in a shell which is covered by a membraneous parapodium from either body side. A pair of rather short, inrolled, and auriculate rhinophores protrude from respective sides of the anterior end of the head. Their lateral groove continues to the eye area situated just behind the base of rhinophore on the lateral side of the head. The uppermargin of the eye area is folded very slightly to form insignificantly an overhanging pent roof. A few to sometimes many small conical papillae are distributed all over the body surface inclusive of the tail, but excepting the neck, head and rhinophores; these papillae are never branched. The spout of the shell is situated on the posterior margin of the visceral hump and usually slightly dislocated to the right side. The tail is slender, about twice as long as the visceral mass or sometimes more, and with a longitudinal crest along the median line on the dorsal surface. Sometimes, the tail may be cut off by autotomy (Pl. I, Fig. D), although some days later a tail regenerated from the remaining basal portion of the lost tail will be observed ( $\mathrm{Pl}$. I, Fig. E).

The ground colouration of the body is grass green, but may be tinged with pale yellowish brown in various degrees. Many minute dark (black, dark blue, or dark brown) points are scattered on the whole surface of the body, but rhinophores and the tail; the latter may be, however, sometimes furnished with a few of such points. The colour pattern of the body, on the other hand, of the specimens examined in the present study are classified into the following three types according to the features of 
the blue spots found on the dorsal surface of the trunk and the tail as seen in Pl. I. Type I: Blue spots are each encircled with a yellowish or orange ring and take a feature of ocelli on the dorsal surface of the trunk, head, parapodium and the anterior fold of the foot (Pl. I, Fig. A).

Type II: Blue spots never form the ocelli encircled with a yellowish or orange ring even on the trunk and the head (Pl. I, Figs. B and E).

Type III: Blue spots such as Types I and II are wholly missing on the body surface (Pl. I, Fig. C).

Probably these three pattern types might be continued one another though such intermediate specimens as those collected from Amami-oshima Island in March 1974 and the Cape Shiono-misaki in March 1977, in which a few of the blue spots arranged along the inner margin of the dorsal surface of the parapodium are encircled with a faint yellowish orange ring and foreshow the formation of ocelli (Pl. I, Fig. E). Rather small blue spots on the dorsal surface of the folded margin of the foot are variable, too; they are sometimes replaced in variable degrees with brownish coloured spots (Pl. I, Fig. B), or may disappear completely. Rhinophores are lightly coloured yellow and sometimes furnished with one to three bluish bands.

The shell is calcified, but thin and fragile. It is slightly flattened and rounded in outline when it is seen from the dorsal or ventral side (Fig. 1, A and B). The colouration is milky white and glossy. The shell is covered by a thin, colourless and transparent epidermis. The apex of the body whorl is slightly sunken below the top level of the shell, which is represented by the upper side of the outerlip forming the sutural slit; thus the apex is never seen from the lateral side (ap.). The sutural slit is panelled with a slightly arched thin calcified membrane (sut. p.) approximately in its inner half (Fig. 1, C-E). For this calcified membrane the word "sutural panel" is proposed here. The free margin of the sutural panel (f. m. sut. p.) arises first nearly vertically from the side of the sunken apex of the top of the body whorl, but soon is bent horizontally (Fig. 1, D). Therefore, the plane surface of the panel is markedly recurvate around this bending. The cone made of the sutural panel is visible on the top of the shell from the lateral side and looks as if it were the proper spire of the shell (Fig. 1, B). The protoconch is concealed just below the level of the apex of the spiral body whorl, that is usually known as the involute shell, in the state of inversion. It is about $150 \times 200 \mu \mathrm{m}$ in cross diameter and light yellowish brown and translucent (Fig. 2). The shape of the protoconch belongs to the "shell-type 1" defined by Thompson (1961).

The radula is uniserial and the teeth are of a typical ascoglossan style (PI. II). The radula of a specimen collected from Kuro-shima Island on May 31, 1977 consists of 36 teeth in all, 9 teeth in the ascending and 24 teeth in the descending series and 3 pre-radular teeth. Any heaped teeth have not been observed in the radula. The tooth is blade shaped, its cutting edge is slightly curved or almost straight. The effective tooth of this specimen is about $280 \mu \mathrm{m}$ in length and $89 \mu \mathrm{m}$ in height when it is seen from the lateral side; the ratio of length to high is about 1:3.2. The base of the tooth is inconspicuous when it is seen from the lateral side, but in the dorsal 

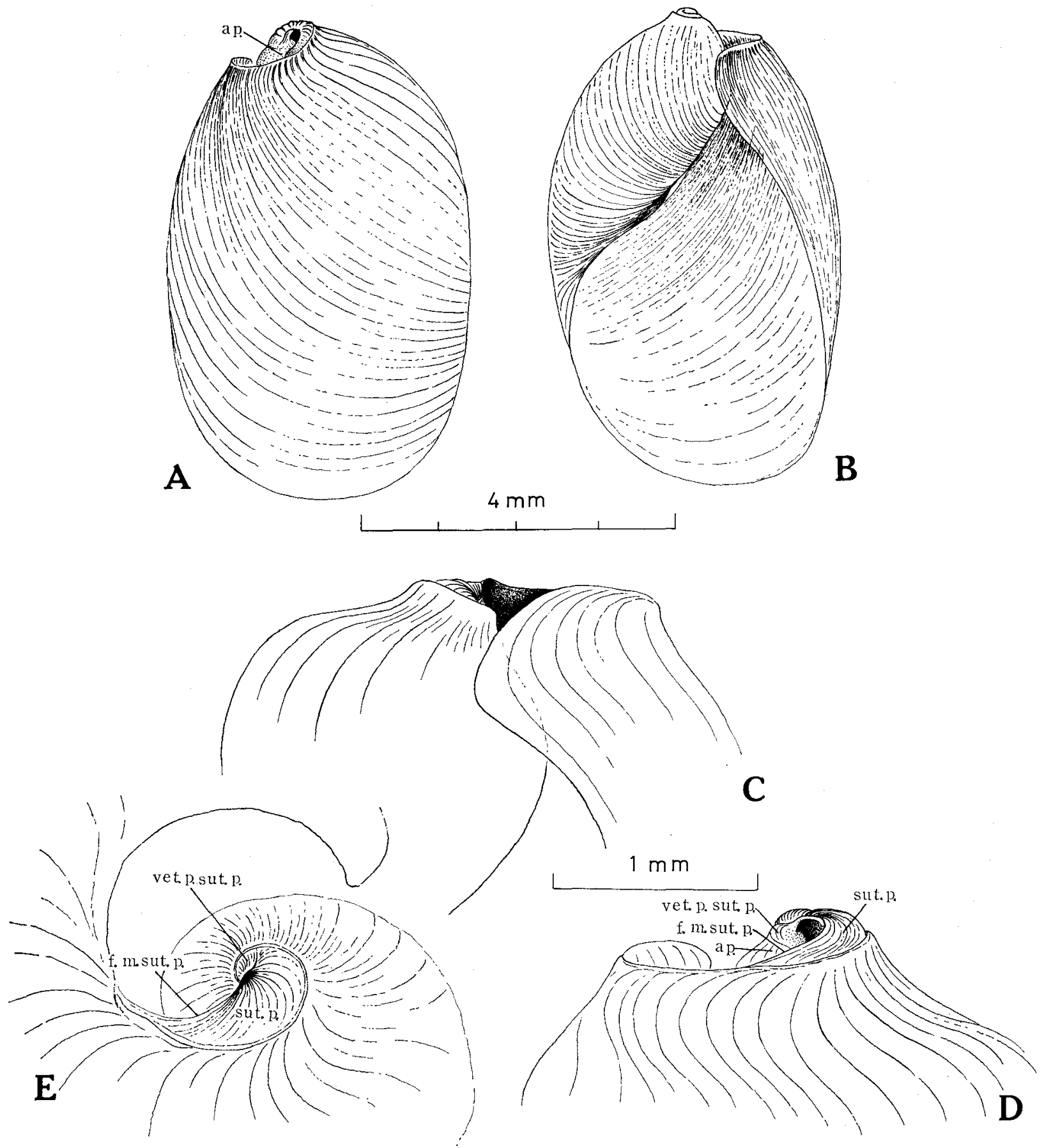

Fig. 1. Oxynoe viridis (Pease, 1861)

A and B: Empty shell of the specimen collected from the Cape Shiono-misaki on May 13, 1972.

A. ... dorsal side, B. ... ventral side.

C-E: Upper part of the shell from a specimen collected from Kuro-shima Island on May 31, 1977.

C. ... ventral side, D ... dorsal side, E. ... apical side.

ap. ... apex of shell. f. m. sut. p. ... free margin of sutural panel. vert. p. sut. p. ... vertical portion of sutural panel. sut. p. ... sutural panel. 




Fig. 2. Oxynoe viridis (Pease, 1861)

Protoconch from the specimen collected from Kabira Bay of Ishigaki-jima Island on April 4, 1977. A. ... from bottom, B. ... from top.

view the base is protruded slightly on both sides as seen in Pl. II, Fig. D. The tooth of another specimen collected from the same locality on May 1, 1977 is $388 \mu \mathrm{m}$ in length and $142 \mu \mathrm{m}$ in breadth, with the ratio of length to breadth about $1: 2.7$; further specimen obtained also at that locality on May 31, 1977 is $266 \mu \mathrm{m}$ in length, 90.5 $\mu \mathrm{m}$ in breadth, and the ratio length/breadth about $1: 2.9$. There is a longitudinal groove along the dorsal median line of the tooth, it is comparatively deep and ending inside the basal end of the tooth. The tooth blade is furnished on each side with a series of many delicate denticles somewhat like a comb.

The male genital pore lies on the right side of the body just behind the eye. The female genital pore is found on the tip of a nipple-like protuberance that is

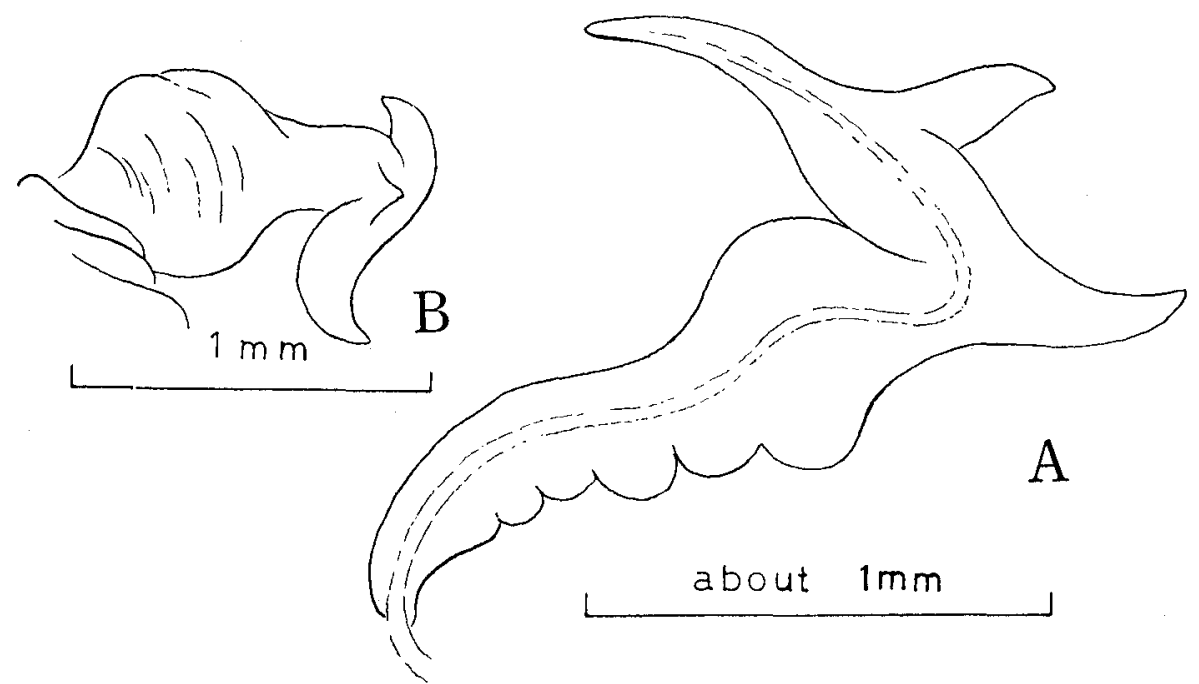

Fig. 3. Oxynoe viridis (Pease, 1861)

A: Penis from a fresh animal collected from Kabira Bay of Ishigaki-jima Island on April 4, 1977.

B : Penis from a preserved animal collected from Kasari of Amami-oshima Island on March 27, 1974. 
protruding as the female papilla at the right anterior corner of the visceral mass a little behind the male aperture. The penis lying in the male atrium unique in having three points (Fig. 3); this type of the penis has been mentioned already by Pruvot-Fol (1960) in O. olivacea and by Marcus and Marcus (1970) in O. antillarum. No penial stylet is observed on the tip of the penis.

The rectum rises up to the dorsal surface at the left anterior corner of the visceral mass and runs to the anus which opens to the pallial cavity on the dorsal surface of the visceral mass at about the level of posterior one third and slightly to the right from the median line. The heart is placed diagonally from the left anterior corner of the visceral mass; the ventricle is laid on the surface at the left anterior corner of the visceral mass and the large auricle is expanded to the whole gill-belt. The gillbelt is formed of a row of many gill folds and hanging down in the cavity from the mantle roof, obliquely over the visceral mass from the middle of the right side to left posterior. The hypobranchial glands are visible as a triangular structure on the right side close to the base of the outermost fold of the gill-belt.

\section{Oxynoe kabirensis Hamatani, spec. nov.}

(Japanese name: Kabirano-tsuyu, nov.)

Materials: Four specimens collected by the present author in March to May 1977 from Ishigaki-jima Island and Kuro-shima Island both in the Yaéyama Islands situated south to the Okinawa Archipelago; all from among the colonies of green algae, Caulerpa racemosa Web. v. Bos. var. clarifera f. macrophysa Web. v. Bos., growing at the low water level on projecting reefs. One specimen found by Mr. K. Kitao in July 1979 in the colony of Caulerpa racemosa Web. v. Bos. var. occidentalis (J. Ag.) Börg. growing at the depth of $1.5 \mathrm{~m}$ on the shore of Bansho-zaki near the Seto Marine Biological Laboratory, Wakayama Prefecture, Middle Japan.

Type locality: Kabira Bay of Ishigaki-jima Island $\left(27^{\circ} 27.5^{\prime} \mathrm{N}\right.$ and $\left.124^{\circ} 08.6^{\prime} \mathrm{E}\right)$. Type specimen series: Holotype specimen, $25 \mathrm{~mm}$ in length, collected on April 5, 1977 by the present author. Paratype specimens Nos. 1 and 2 collected by the author on April 7, 1977 from Kabira Bay; Nos. 3 and 4 collected by the author on April 31, 1977 from Kuro-shima Island; No. 5 collected by K. Kitao near the Seto Marine Biological Laboratory on July 30, 1979.

Description: The living animal is at a glance just the same in shape as the preceeding $O$. viridis. The body varies from 20 to $30 \mathrm{~mm}$ in length in an extended state (Pl. III, Figs. A and B). The head is seemingly smaller than in O.viridis. Several to about a dozen papillae are present on the dorsal surface of the body excepting the head, though the tail may lack these rarely. These papillae are very delicate and usually bi or tri-fid distally, though some of them remain simple. The tail is very long as in $O$. viridis, but seemingly a little more flattened than in that species; both margins are undulating and its median line does not show any trend to form 
a longitudinal crest. The siphon formed by the spout of the shell is usually dislocated slightly to the right side from the median line of the body.

The general body colour varies from greenish yellow to pale yellow, through pale green and dull yellow green. A large triangular area, coloured deep green (in holotype and paratypes Nos. 1 and 4) to light green (paratypes Nos. 2, 3 and 5), is spread on the outside of the parapodium, with its base along the base of the parapodium and the apex at about the middle of the free margin of the parapodium. Small light brownish spots are scattered over the dorsal surface of the body, except the head, the greenish triangular area of the parapdoium and the basal half of rhinophores. The papillae are furnished with a few small spots of chocolate brown.

The shell is very similar to that of $O$. viridis in shape and size (Fig. 4, A and B).
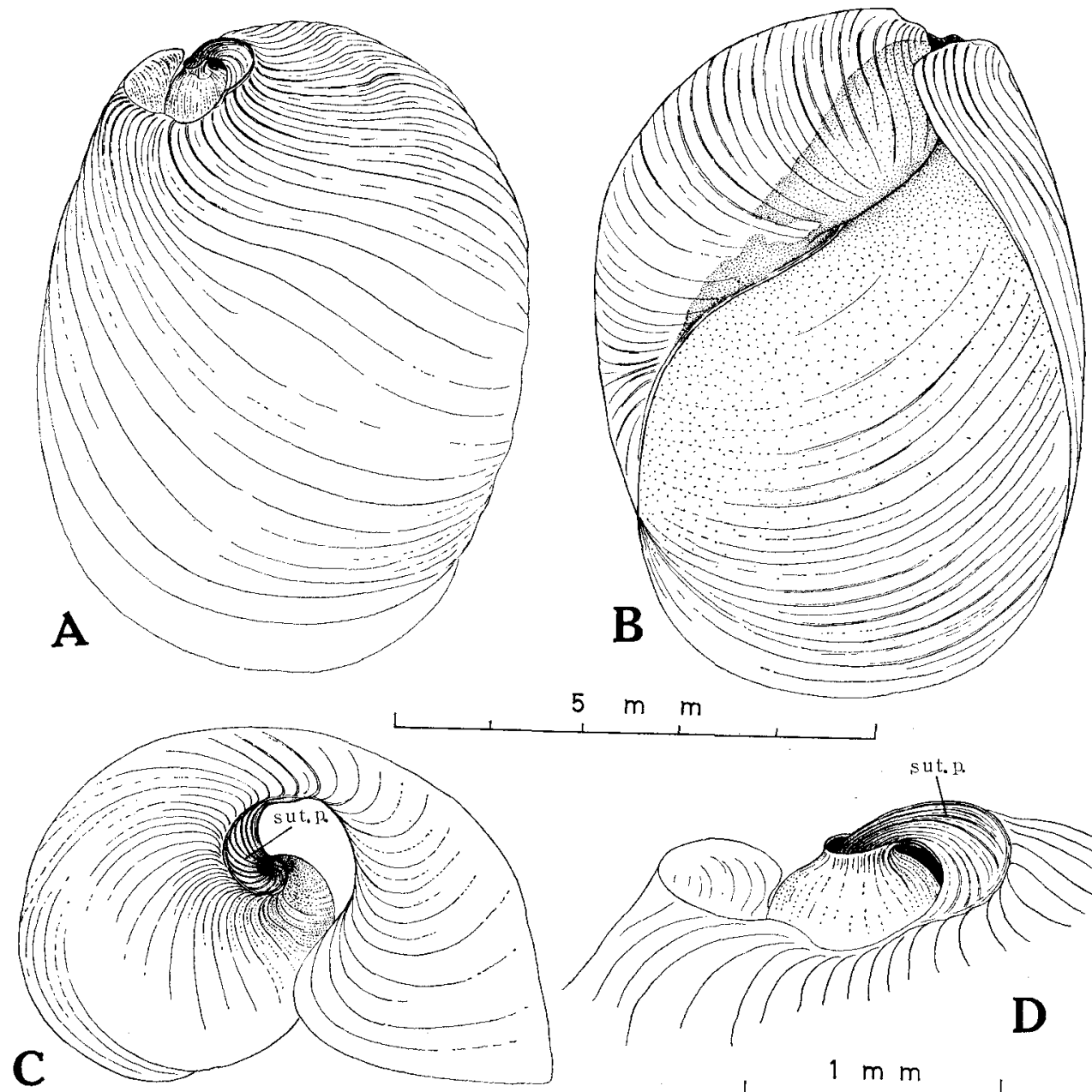

$5 \mathrm{~m} m$

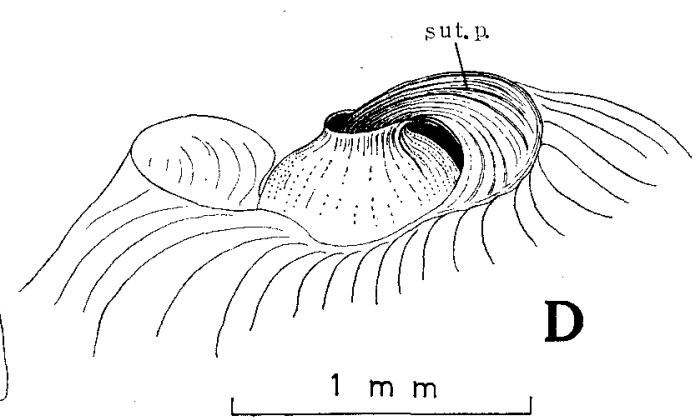

Fig. 4. Oxynoe kabirensis Hamatani, spec. nov.

Empty shell of paratype No. 3. A. ... dorsal side, B. ... ventral side, C. ... apical side,

D. ... dorsal side, magnified. sut. p. ... sutural panel. 
However, the feature of the sutural panel (sut. p. in Fig. 4) differs clearly from that of the preceding species the free margin of the sutural panel is extended out from the apex of the shell, that is sunken within the hollow collared by the outer lip, in a gentle arc and without any bending by the apex. Thus, the plane surface of the panel is never recurvate as in the preceding species. The protoconch is hidden under the sutural panel and largely dislocated from the top of the body whorl (Fig. 5).

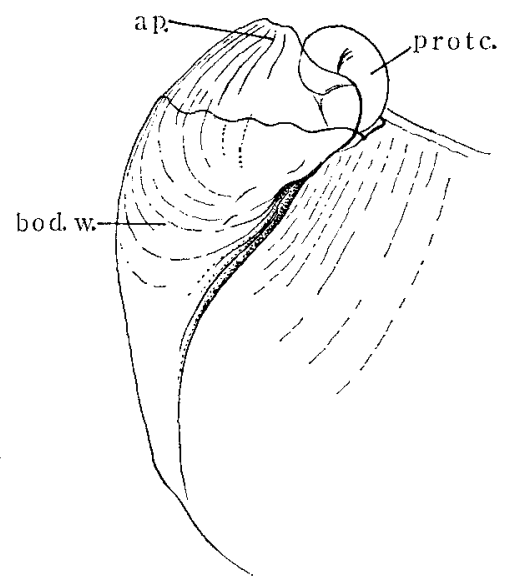

Fig. 5. Oxvnoe kabirensis Hamatani, spec. nov.

Protoconch in its natural situation, paratype specimen No. 2. ap. ... apex of the shell. bod. w. ... body whorl. protc. ... protoconch.

The radula of an examined specimen (paratype No. 3) consists of 23 teeth in total; 17 teeth in the ascending, 6 teeth in the descending series and 5 pre-radular teeth (Pl. III, Fig. C). The tooth (Pl. III, Figs. D and E; Pl. VI, Figs. H and I) is very similar to that of $O$. viridis; it is uniserial and of a typical sacoglossan style. It is somewhat wider than in the preceding species. The effective tooth, when seen from the lateral side, is $272 \mu \mathrm{m}$ in length and $91 \mu \mathrm{m}$ in height, the ratio of length to height about 1:3.0. The last tooth of the ascending series is $297 \mu \mathrm{m}$ in length when it is seen from the ventral side. Its base is wider than in $O$. viridis, $168 \mu \mathrm{m}$ in breadth, $52 \mu \mathrm{m}$ in thickness and the ratio of length to breadth about $1: 1.8$.

The penis of paratype No. 5 was observed in a living state. It is somewhat sickle-shaped, with a large roundish protuberance at the bending point (Fig. 6). If this protuberance can be regarded as a point, the penis of this new species may be expressed as two-pointed. The distal half of the penis tapers to its end in a gentle curve and is nearly equal in length with the proximal half which is muscular and somewhat broader than the distal half. No penial stylet is found at the tip of the penis. A muscle starts from the basal portion of the proximal half and also from the protuberance at the base of the distal half respectively. The slender vas deferens runs first along the outside of the proximal half after leaving the proximal end of the penis and then turns to the male organ in the visceral mass. 


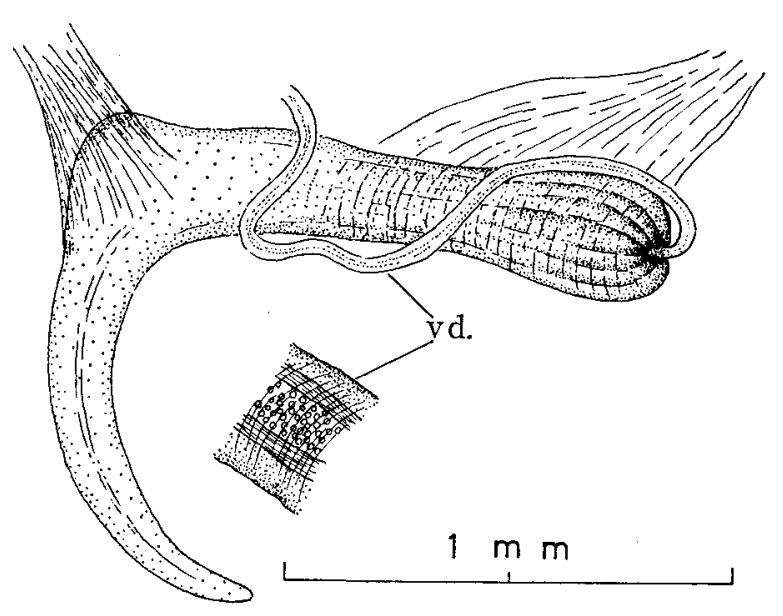

Fig. 6. Oxynoe kabirensis Hamatani, spec. nov.

Penis of the fresh animal, paratype No. 5. vd. ... vas deferens running along the proximal half of the penis.

\section{Remarks}

The species, Oxynoe viridis, was established by Pease in 1861 as a species belonging to the genus Lophocercus Krohn, 1847 on a specimen collected from among the sea-weeds on the sandy bottom in shallow water of Huaheine, the Tahiti Archipelago. According to the original description, the "Body ......; the whole upper surface garnished with more or less numerous, cirrigerous appendages. Colour .....; some are minutely dotted with brown, other with a few blue dots, margined with black rings along the edge of the lateral lobes and on the neck". Later, Eliot (1906) described the six specimens collected from Zanzibar under the name of Lophocercus viridis, there the "Colour bright yellowish green, covered with rings of dull yellow. The inside of each ring is bright blue, and each blue area has a clear black spot in the centre." The figures of the whole animal and the shell of $L$. viridis were given for the first time by Pease in 1868 (Pl. 8, figs. 1 and 2; Pl. 12, fig. 25). From the figures given by Pease, it is supposed that the Pease's specimen was bearing some appendages on the neck, head and rhinophores. These features seen in the description and figures given by Pease are clearly different from the features of the specimens of $O$. viridis treated in the present paper in the following two points: (1) no appendages are found on the neck, head, and especially on rhinophores in the Japanese specimens, and (2) in ocelli, the blue spots are margined with the yellowish orange in the Japanese specimens instead of the black ring in the Pease's specimen. If those features given by Pease as to the above-mentioned two points are confirmed again on newly collected specimens and accepted as the specific criteria, the Japanese specimens described in the present paper as $O$. viridis will need a different name as a new species. Unfortunately, any specimens from the type locality and fitting the Pease's description and figures have been inaccessible to the present author. On 
the other hand, the black spot at the centre of the blue area encircled by a ring of dull yellow, that is indicated in the description of ocelli by Eliot (1906), reminds the present author of the existence of a very dark blue spot at the centre of ocelli in the Japanese specimens in some rare cases. The difference between the black and dark blue spots in the ocellus may safely be accepted merely as an intraspecific variation. Hence, the specimens of Fliot are judged to be identical with the present Japanese specimens.

The new species, Oxynoe kabirensis, is easily separated from $O$. viridis by the features of the soft body, radula and the penis. And the shell of the present new species is clearly separable from that of $O$. viridis, too, by the feature of the sutural panel, that is seemingly reflecting faithfully the evolution rate of the outer lip and the level difference between the upper margin of the outer lip and the apex of the shell; otherwise it is very difficult to show these by description. On the other hand, it is hardly possible to make the exact comparison between the present new species and other known species else than $O$. virdis, that are mostly defined on the morphology of the shell, as the shell of these species is not described so completely as to refer to the structure of the sutural panel. Therefore, the establishment of the present new species leaves some questions for future studies and at the same time proposes further observation of the live specimen and detailed examination of the shell in already known species.

\section{REFERENCES}

Baba, K. 1952. Record of an ascoglossan mollusk, Oxynoe viridis (Pease) from Sagami Bay, Japan. Venus, vol. 17 , no. 2.

1955. Opisthobranchia of Sagami Bay, Supplement, collected by His Majesty the Emperor of Japan. Iwanami Shoten, Tokyo.

Burn, R. 1966. The opisthobranchs of a Caulerpan microfauna from Fiji. Proc. Malac. Soc. Lond., vol. 37.

Eliot, G. 1906. Nudibranchs and tectibranchs from the Indo-Pacific. II. Notes on Lophocercus, Lobiger, Haminaea, and Newnesia. J. Conchol. vol. 11, no. 10.

Engel, H. 1927. Westindishe Opisthobranchiate Mollusken. II. Bijdr. Dierk., 25.

Gascoigne, T. and Sartory, P.K. 1974. The teeth of three bivalved gastropods and three other species of the order Sacoglossa. Proc. Malac. Soc. Lond., vol. 41, Pt. 2.

Habe, T. 1949. The genus Oxynoe, new to Japanese molluscan fauna. Venus, vol. 15, nos, 5-8.

Marcus, Ev. and Marcus, Er. 1963. Opisthobranches from the Lesser Antilles. Studies on the fauna of Curaçao and other Caribbean Islands. vol. 19.

1967. American Opishobranch mollusks. Pt. 1. Tropical American opisthobranchs. In: Studies in Tropical Oceanography, No. 6. Stud. trop. Oceanogr. Miami 6.

1970. Opisthobranchs from Curaçao faunistically related regions. Stud. Fauna Curaçao, vol. 33 , no. 122 .

Marcus, Ev. and Hughes, H.P.I. 1974. Opisthobranch mollusks from Barbados. Bull. Mar. Sci., vol. 24, no. 3.

Melvill, M.A. 1918. Descriptions of thirty-four species of marine mollusca from the Persian Gulf, Gulf of Oman, and Arabian Sea, collected by Mr. F.W. Townsend. Ann. Mag. Nat. Hist., Ser. 9 , vol. 1 .

Mörch, M.O.A.L. 1863. Contributions à la faune malacologique des Antilles danoises. Journ. de Conchyl., vol. 11. 
1863. Révision des espèces du genre Oxynoe, Rafinesque, et Lobiger, Krohn. Journ. de Conchyl., vol. 11 .

Nevill, G. and Nevill, H. 1869. On some new marine Gastropoda from the Southern Province of Ceylon. Journ. Asiat. Soc. Bengal. vol. 38, Pt. 2, no. 2.

Pease, W.H. 1861. Descriptions of new species of Mollusca from the Pacific Islands. P.Z.S.

1868. Descriptions of marine Gastropodae, inhabiting Polynesia. Amer. Journ. Conch., vol. 4 , no. 2.

Pilsbry, H.A. 1895-6. Manual of Conchology, vol. 16, Opisthobranchiata.

Pruvot-Fol, A. 1954. Mollusques opisthobranches. In: Faune de France, 58. Paul Lechevalier, Paris.

Thompson, T.E. 1977. Jamaican Opisthobranch molluscs I.J. moll. Stud., 43.

Warmke, G.L. and Almodóvar, L.R. 1972. Observations on the life cycle and regeneration in Oxynoe antillarum Mörch, an ascoglossan opisthobranch from the Garibbean. Bull. Mar. Sci., vol. 22, no. 1. 


\section{EXPLANATION OF PLATES I-IV}

Plate I: Oxynoe viridis (Pease, 1861)

A-C: Three patterns of body colouration seen in the animals collected from Kabira Bay of Ishigaki-jima Island on April 5, 1977.

A.....Type I, $27 \mathrm{~mm}$ long; B.....Type II, $30 \mathrm{~mm}$ long; C.....Type III, $24 \mathrm{~mm}$ long.

D : An animal lost its tail by autotomy; collected at Kabira Bay of Ishigaki-jima Island on April 5, 1977.

E : An animal with the short tail newly regenerated, collected from Yo of Amami-oshima Island on March 29, 1974.

Plate II: Oxynoe viridis (Pease, 1861)

A : Whole radular teeth of the specimen collected from kuro-shima Island on May 31, 1977.

$B$ : Effective tooth of the same specimen, seen from the lateral side.

C : Pre-radular teeth 1-3 of the same specimen.

D : A tooth from an other specimen collected from kuro-shima Island on May, 1977, seen from the dorsal side.

pre-rad. t. 1-3...... Pre-radular teeth 1-3.

Plate III: Oxynoe kabirensis Hamatani, spec. nov.

A : Holotype, living animal seen from the dorsal side.

B : The same, from the right side.

C : Whole radular teeth of paratype No. 3 .

D : A tooth from the same specimen, seen from the ventral side.

E : Effective tooth from the same specimen, seen from the lateral side.

Plate IV: A-F: Oxynoe viridis (Pease, 1861)

A : Protoconch of the specimen collected from Kabira Bay of Ishigaki-jima Island on April 4, 1977, from above (the same one shown in Text-fig. 2).

$\mathrm{B}:$ Apical portion of the shell shown in Text-fig. 1, E.

G : A tooth from a specimen collected from Kuro-shima Island on May 3, 1977, seen from the dorsal side.

D : Another tooth from the same specimen, seen from the ventral side.

E : A tooth from the same specimen, seen from the lateral side.

F : Comb of denticles garnishing both sides of the tooth in the same specimen, seen from the lateral side of the tooth.

G-I: Oxynoe kabirensis Hamatani, spec. nov.

G : Protoconch of paratype No. 2 the same one shown in Text-fig. 5.

$\mathrm{H}$ : A tooth from the same paratype, seen from the ventral side.

I : Another tooth from the same paratype, seen from the lateral side.

All photographs by scanning electron microscope. 
Publ. Seto Mar. Biol. Lab., XXV (5/6), 1980

PLATE I


I. Hamatani: Genus Oxynoe from Japan 
Publ. Seto Mar. Biol. Lab., XXV (5/6), 1980

PLATE II

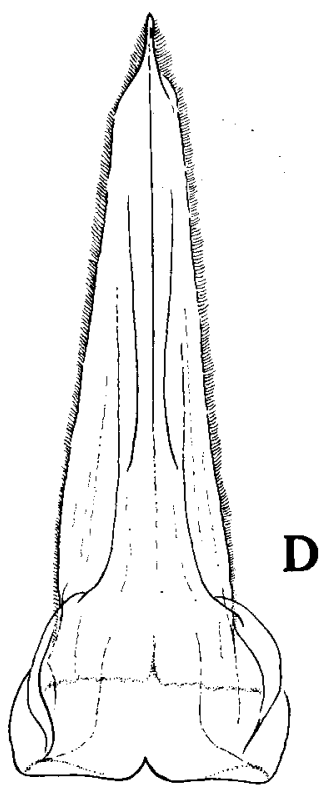

$150 \mu$

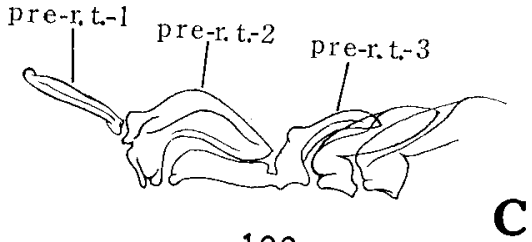

$100 \mu$



B



I. Hamatani: Genus Oxynoe from Japan 

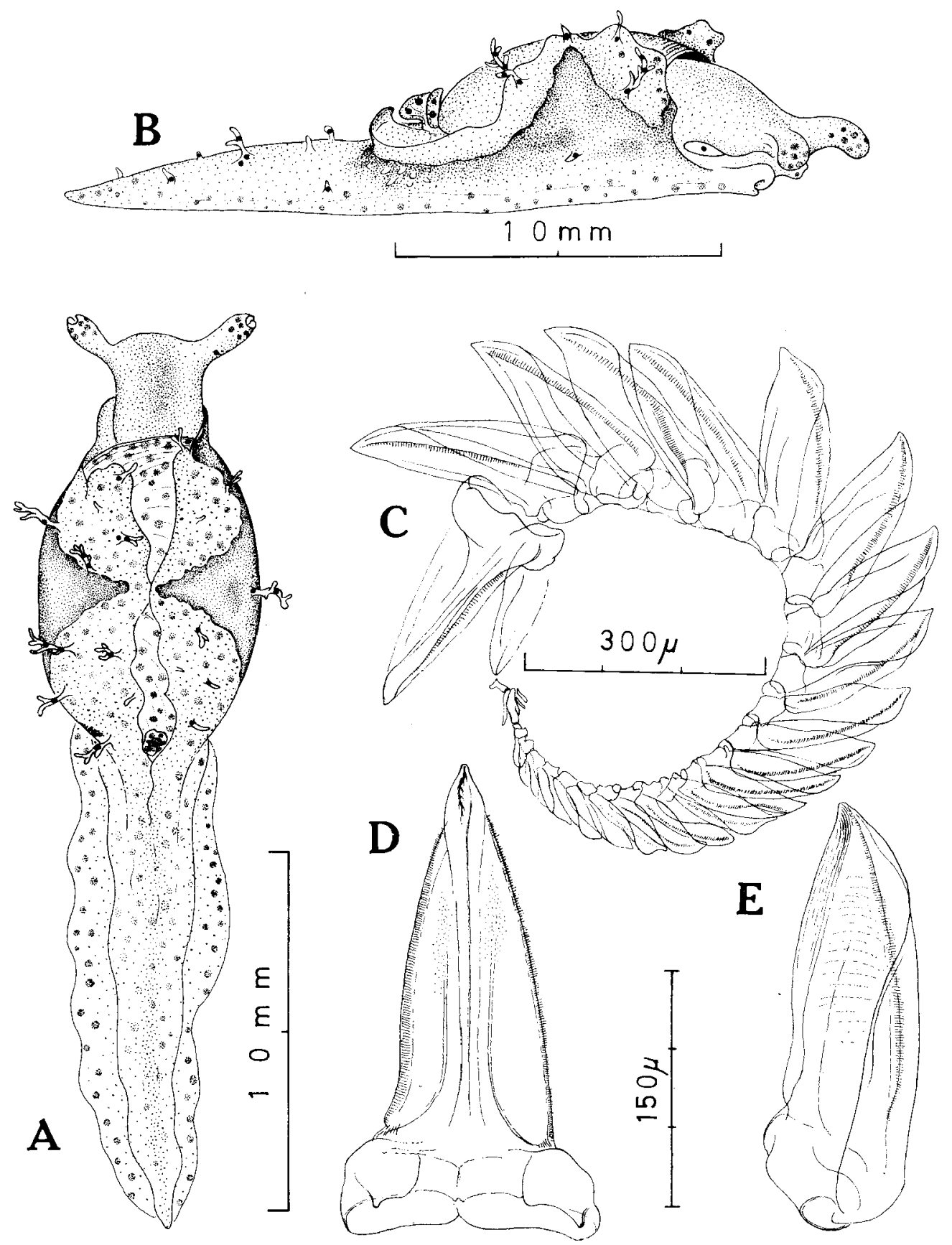

I. Hamatani: Genus Oxynoe from Japan 
Publ. Seto Mar. Biol. Lab., XXV (5/6), 1980

PLATE IV
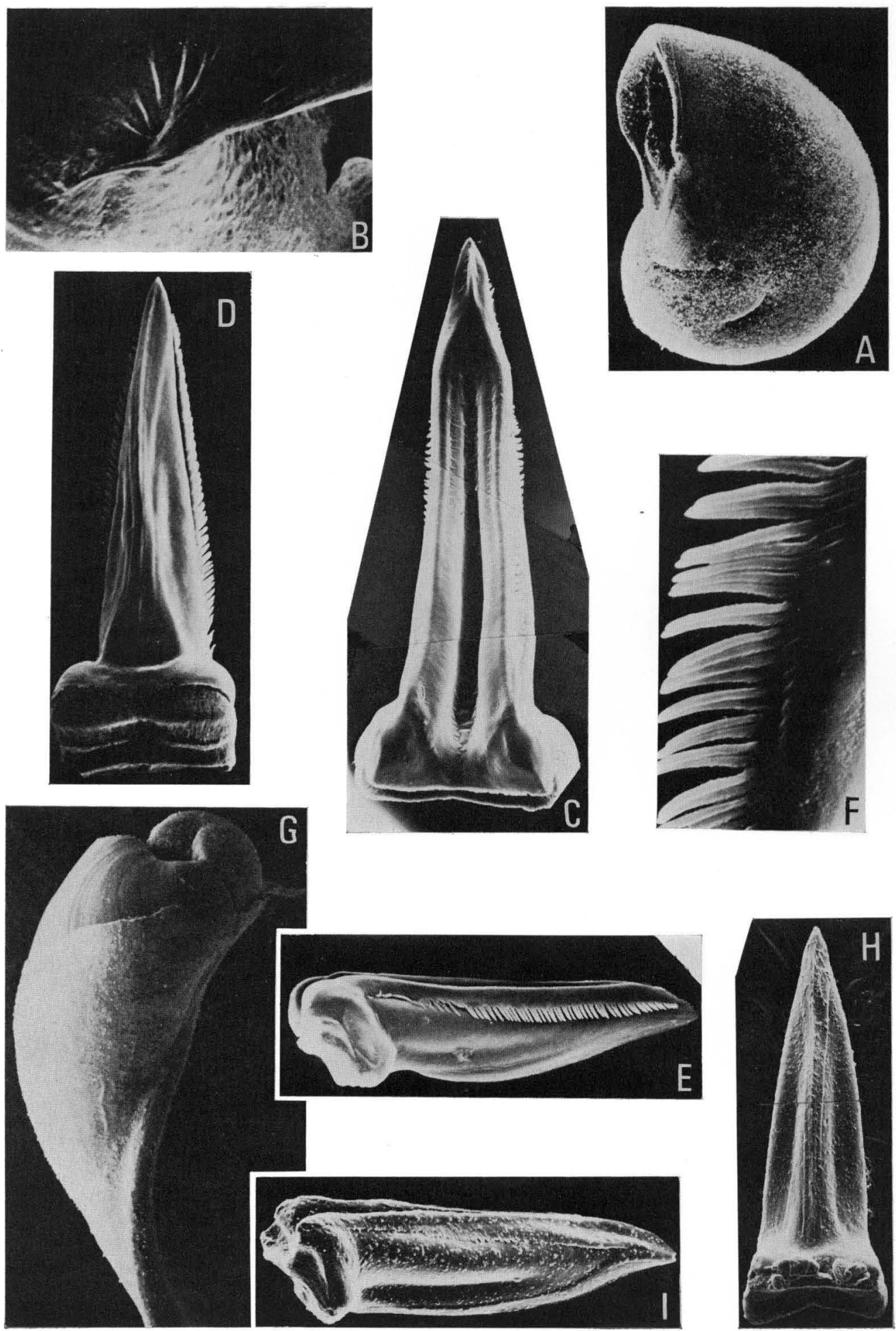

I. Hamatani: Genus Oxynoe from Japan 